\title{
ANALISIS IMPLEMENTASI KEBIJAKAN SEKOLAH RAMAH ANAK DI DEPOK
}

\section{Safitri Rangkuti dan Irfan Ridwan Maksum}

Fakultas Ilmu Administrasi, Universitas Indonesia, Indonesia

qqrangkuti@gmail.com

\begin{abstract}
Child-friendly and child-based schools are an effort to fulfill children's rights and provide quality education for children. This study aims to explain the implementation of Child Friendly School Policies established by the Ministry of Women's Empowerment and Child Protection and analyze the supporting and inhibiting factors for the implementation of Child Friendly School Policies in SMP Negeri 6 Depok. This study used a qualitative method that shows the implementation of the Child Friendly School Policy in SMPN 6 Depok been going well, assessed in the context of the process, results (output), impact (outcomes) and causality (causal connection).The factors that support the implementation of the Child Friendly School Policy at SMP Negeri 6 Depok are good and smooth communication, attitudes and commitment of all school people, coordination between the Depok Government and the School and the positive support of all school members, parents, surrounding communities. However, there are still obstacles, namely the limited school budget and the number of teachers, and the density of teacher activities that have caused the implementation of policies to be not optimal.
\end{abstract}

Keywords : Policy Implementation, Child, and Child Friendly School

\section{ABSTRAK}

Sekolah yang ramah anak dan berbasis hak anak merupakan upaya memenuhi hak-hak anak dan memberi pendidikan yang berkualitas bagi anak. Penelitian ini bertujuan untuk menjelaskan implementasi Kebijakan Sekolah Ramah Anak yang ditetapkan oleh Kementerian Pemberdayaan Perempuan dan Perlindungan Anak dan menganalisis faktor pendukung dan penghambat implementasi Kebijakan Sekolah Ramah Anak di SMP Negeri 6 Depok. Penelitian ini menggunakan metode kualitatif yang menunjukan implementasi Kebijakan Sekolah Ramah Anak di SMP Negeri 6 Depok sudah berjalan baik, dinilai dalam konteks proses, hasil (output), dampak (outcome) dan hubungan sebab akibat (causal connection). Faktor-faktor yang mendukung implementasi Kebijakan Sekolah Ramah Anak di SMPN 6 Depok adalah komunikasi yang baik dan lancar, sikap dan komitmen seluruh warga sekolah, koordinasi antara Pemda Depok dengan Sekolah serta adanya dukungan positif seluruh warga sekolah, orang tua, masyarakat sekitar. Namun masih terdapat hambatan yaitu terbatasnya anggaran sekolah dan jumlah guru serta padatnya aktivitas guru menyebabkan pelaksanaan kebijakan belum optimal.

Kata Kunci: Implementasi kebijakan, Anak, Sekolah Ramah 


\section{PENDAHULUAN}

Kasus kekerasan di lingkungan sekolah umumnya meliputi dari anak pelaku kekerasan dan bullying, anak korban kekerasan dan bullying, anak korban tawuran dan anak pelaku tawuran anak korban Kebijakan Pendidikan yakni pungli, dikeluarkan dari sekolah, tidak boleh ikut ujian dan putus sekolah. Umumnya kekerasan dilakukan oleh tenaga pendidik dan peserta didik. Dari semua fakta yang ada di lapangan dapat disimpulkan bahwa sekolah belum bisa menjadi tempat yang memberikan keamanan dan kenyamanan bagi anak. Padahal waktu anak berada di lingkungan sekolah kurang lebih 8 (delapan) jam atau 1/3 (sepertiga) hari.

Pemerintah Kota Depok dalam upaya memenuhi hak anak dan melindungi anak telah melaksanakan Kebijakan Kota Layak Anak sejak dikeluarkannya Peraturan Daerah Kota Depok Nomor 15 Tahun 2013 tentang Penyelenggaraan Kota Layak Anak dan Peraturan Walikota Depok Nomor 10 Tahun 2017 tentang Pengembangan Kota Layak Anak. Kota Depok mendapat predikat Kota Layak Anak sejak tahun 2014 berdasarkan evaluasi Kementerian Pemberdayaan Perempuan dan Perlindungan Anak (PPPA) Republik Indonesia. Pada tahun
2014 Depok mendapat predikat Kota Layak Anak Pratama hingga pada tahun 2017 dan 2018 Kota Depok meraih predikat Kota Layak Anak Nindya.

Untuk menjamin pemenuhan hak anak seperti kesehatan, keamanan dan kenyamanan anak di sekolah, Kementerian Pemberdayaan Perempuan dan Perlindungan Anak mengeluarkan Peraturan Menteri PPPA Nomor 8 Tahun 2014 tentang Kebijakan Sekolah Ramah Anak yang merupakan bagian dari indikator Kebijakan Kabupaten/Kota Layak Anak. Berdasarkan Peraturan Menteri PPPA Nomor 8 Tahun 2014 disebutkan bahwa "Sekolah Ramah Anak (SRA) merupakan salah satu indikator Kabupaten/Kota Layak Anak (KLA)" sebagaimana diatur dalam Peraturan Menteri Pemberdayaan Perempuan dan Perlindungan Anak (PPPA) No. 12 Tahun 2011 tentang Indikator Kabupaten/Kota Layak Anak (KLA) Pasal 11 menyebutkan bahwa "Klaster Pendidikan, Pemanfaatan Waktu Luang dan Kegiatan Budaya meliputi: (a) angka partisipasi Pendidikan usia dini; (b) persentase wajib belajar Pendidikan 12 (dua belas) tahun; (c) persentase Sekolah Ramah Anak; (d) Jumlah sekolah yang memiliki program, sarana dan prasarana perjalanan masuk ke dan 
dari sekolah dan (e) tersedia fasilitas untuk kegiatan kreatif dan rekreatif yang ramah anak, di luar sekolah, yang dapat diakses semua anak".

Sekolah Ramah Anak merupakan sebuah konsep yang ideal untuk anak usia sekolah. Pada sekolah ramah anak semua pendidikan berpusat pada anak dan proses belajar harus didukung oleh keadaan sosial, fisik dan emosional yang positif, sehat dan aman. UNICEF telah mengembangkan kerangka kerja sistem dan pendidikan sekolah berbasis hak anak yang memiliki ciri yaitu "inklusif, sehat dan protektif untuk semua anak, efektif dengan anak-anak, dan terlibat dengan keluarga, masyarakat dan anak-anak" (Shaeffer, 1999).

Indikator Sekolah Ramah Anak meliputi enam komponen penting yaitu : (1) Kebijakan Sekolah Ramah Anak (SRA); (2) Pelaksanaan Kurikulum; (3) Pendidikan dan Tenaga Kependidikan terlatih Hak-Hak Anak; (4) Sarana dan Prasarana Sekolah Ramah Anak; (5) Partisipasi Anak, (6) Partisipasi Orang tua, Lembaga Masyarakat, Dunia Usaha, Pemangku Kepentingan lainnya dan Alumni.

Implementasi Kebijakan Sekolah Ramah Anak di Kota Depok telah dimulai sejak tahun 2016 dengan dikeluarkannya Surat Keputusan Kepala Diknas Pendidikan Kota Depok Nomor: 421/4814-Disdik/2016 tentang Penetapan Sekolah Ramah Anak Kota Depok Sebagai Penyelenggara Pendidikan Sekolah Ramah Anak Tahun Pelajaran 2016/2017, pada awal ditetapkannya Sekolah Ramah Anak di Kota Depok baru terdapat 116 Sekolah Ramah Anak dan jumlah sekolah terus berkembang sampai tahun 2018 dengan dikeluarkannya Surat Keputusan Kepala Diknas Pendidikan Kota Depok Nomor : 421/0072-Disdik/2018 tentang Penetapan Sekolah Ramah Anak Kota Depok Sebagai Penyelenggara Pendidikan Sekolah Ramah Anak Tahun Pelajaran 2017/2018, saat ini sudah terdapat 296 Sekolah Ramah Anak di Kota Depok yang meliputi 188 SRA di tingkat Sekolah Dasar (SD) dan 108 SRA di tingkat Sekolah Menengah Pertama (SMP).

Kebijakan Sekolah Ramah Anak di Kota Depok telah berjalan selama dua tahun namun masih saja ditemui kasus kekerasan di lingkungan sekolah bahkan terjadi di Sekolah yang telah menyandang Sekolah Ramah Anak. Banyak sekolah yang belum memiliki program/kegiatan terkait Sekolah Ramah Anak sehingga masih sekedar predikat Sekolah Ramah 
Anak. Penelitian ini akan menganalisis Implementasi Kebijakan Sekolah Ramah Anak di SMP Negeri 6 Depok dengan yang merupakan salah satu indikator untuk mewujudkan Kota Layak Anak dalam bidang pendidikan. Dengan adanya Penelitian ini diharapkan implementasi Kebijakan Sekolah Ramah Anak di Kota Depok dapat memberikan hasil dan dampak yang positif yang dapat dirasakan oleh anak dan masyarakat.

\section{METODE}

Penelitian Implementasi Kebijakan Sekolah Ramah Anak dalam Mewujudkan Kota Layak Anak di Kota Depok ini menggunakan pendekatan post postivis dengan metode pengumpulan data kualitatif. Pendekatan ini digunakan oleh penulis untuk menggali informasi dari narasumber atau para informan yang membantu dalam menganalisis Implementasi Kebijakan Sekolah Ramah Anak di SMP Negeri 6 Depok.

Narasumber dalam penelitian ini adalah Dinas Pemberdayaan Anak Masyarakat dan Keluarga, Dinas Pendidikan, Kepala Sekolah, Guru, Anak Murid, Orang Tua, KPAI dan Psikolog. Penelitian dilakukan tahun 2019 dengan lokasi penelitian SMP Negeri 6, Cilodong, Kota Depok.
Teknik pengumpulan data yang digunakan untuk mendapatkan informasi dan data dilakukan melalui wawancara, studi kepustakaan (literature), dokumentasi, observasi. Dalam menganalisis data dilakukan dengan pengumpulan data, reduksi data, penyajian data dan penarikan kesimpulan. Berdasarkan hal tersebut penelitian ini menghasilkan informasi dan data-data lapangan tentang implementasi Kebijakan Sekolah Ramah Anak dan faktor pendukung dan penghambat implementasi Kebijakan Sekolah Ramah Anak di SMP Negeri 6 Depok.

Kota Depok merupakan salah satu kota yang meraih prestasi Kota Layak Anak tingkat Nindya di Jawa Barat. Sekolah Ramah Anak adalah salah satu indikator pemenuhan hak anak yang berada di kluster empat (Pendidikan, Waktu Luang, dan Kegiatan Budaya). Sampai dengan tahun 2018, Kota Depok memiliki 296 Sekolah Ramah Anak yang meliputi 188 SRA di tingkat Sekolah Dasar (SD) dan 108 SRA di tingkat Sekolah Menengah Pertama (SMP) namun masih terdapat kekerasan di lingkungan sekolah. Fakta di lapangan banyak ditemui sekolah-sekolah negeri berbagai kota/kabupaten yang dipasangi spanduk bertuliskan Sekolah Ramah 
Anak, namun pengetahunan guru sangat minim tentang program yang sudah dijalankan dan dikembangkan dalam rangka Sekolah Ramah Anak (SRA). Belum terlihat rencana program pelatihan yang sistemik untuk peserta didik, atau untuk orang tua, dan untuk para guru yang berguna bagi mereka dalam rangka pembangunan sistem dan budaya perlindungan anak yang tangguh di sekolah dan dalam rangka pemenuhan hak-hak anak secara menyeluruh di lingkungan sekolah dan tidak sedikit kabupaten/kota yang telah mendeklarasikan diri sebagai Kota Layak Anak namun ternyata masih banyak yang sunyi dari aktivitas program-program disertai anggaran yang bisa diandalkan bagi penguatan sistem dan budaya perlindungan anak yang tangguh dan untuk pemenuhan hak-hak anak secara menyeluruh. Berdasarkan latar belakang tersebut maka peneliti mengambil sampel penelitian Implementasi Kebijakan Sekolah Ramah Anak di Kota Depok.

\section{Lokasi penelitian adalah SMP Negeri} 6 Depok karena sekolah yang berada di Kecamatan Cilodong Depok Jawa Barat. Pemilihan lokasi penelitian ini karena di sekolah tersebut karena Depok merupakan salah satu Kota Layak Anak kategori Nindya pada tahun 2017 dan
2018 dan SMP Negeri 6 Depok merupakan sekolah yang telah menerapkan Kebijakan Sekolah Ramah Anak seperti antara lain telah menjadi sekolah inklusi, adanya kebijakan anti kekerasan, pembinaan guru tentang anti kekerasan, sarana prasarana sekolah cukup mendukung sekolah ramah anak dan beberapa indikator pendukung lainnya. SMP Negeri 6 Depok merupakan salah satu sekolah yang dipilih sebagai percontohan Sekolah Ramah Anak pada tahun 2016.

\section{HASIL DAN PEMBAHASAN}

Implementasi Kebijakan Sekolah Ramah Anak di SMPN 6 Depok dalam mendukung Kota Layak Anak di Depok.

Kebijakan Sekolah Ramah Anak (SRA) sudah diterapkan di SMP Negeri 6 Depok sejak tahun 2016. Dinas Pendidikan Kota Depok menunjuk 116 sekolah dari tingkat Sekolah Dasar sampai Sekolah Menengah Atas sebagai percontohan Sekolah Ramah Anak di Kota Depok melalui Surat Keputusan Kepala Diknas Pendidikan Kota Depok Nomor: 421/4814-Disdik/2016 tentang Penetapan Sekolah Ramah Anak Kota Depok Sebagai Penyelenggara Pendidikan Sekolah Ramah Anak Tahun Pelajaran 2016/2017. Pada awal ditetapkannya Sekolah Ramah Anak, 
Dinas Pendidikan Kota Depok dalam menunjuk sekolah sebagai piloting atau percontohan berdasarkan indikator sarana dan prasarana yang dinilai sudah memenuhi standar Sekolah Ramah Anak.

Sekolah Ramah Anak bukan sekedar sarana dan prasarana yang memenuhi kebutuhan anak melainkan yang perlu ditekankan adalah adanya komitmen dari sekolah yang menginginkan terwujudnya SRA. Seluruh elemen sekolah harus berkomitmen ini tidak hanya dari kepala sekolah, guru dan murid namun orang tua dan masyarakat sekitar juga turut berkomitmen. Hal penting lainnya adalah tata tertib sekolah yang dibuat berdasarkan kesepakatan semua elemen sekolah (guru dan murid). Adanya peran serta murid baik secara langsung maunpun tidak lansung dalam penyusunan tata tertib, aturan atau kebijakan sekolah lainnya. Dengan adanya kebijakan ini sistem pembelajaran dan pengajaran seharusnya disesuaikan tujuan Kebijakan SRA dengan menerapkan disiplin namun tanpa memberi hukuman yang berupa kekerasan fisik maupun mental anak. Pemahaman pembelajaran anti kekerasan harus membudaya di lingkungan sekolah namun ironinya sampai saat ini masih saja terdapat guru yang menggunakan paradigma menghukum murid dengan kekerasan seperti mencubit, memukul, membentak dan lain sebagainya

Sekolah Ramah Anak merupakan sebuah konsep yang ideal untuk anak usia sekolah. Pada sekolah ramah anak semua pendidikan berpusat pada anak dan proses belajar harus didukung oleh keadaan sosial, fisik dan emosional yang positif, sehat dan aman. UNICEF telah mengembangkan kerangka kerja sistem dan pendidikan sekolah berbasis hak anak yang memiliki ciri yaitu inklusif, sehat dan protektif untuk semua anak, efektif dengan anak-anak, dan terlibat dengan keluarga, masyarakat dan anak-anak.

Tujuan dari Sekolah Ramah Anak untuk mencegah kekerasan terhadap anak dan warga sekolah lainnya, mencegah anak mendapatkan kesakitan karena keracunan makan dan lingkungan yang tidak sehat, mencegah kecelakaan di sekolah yang disebabkan prasarana maupun bencana alam, mencegah anak menjadi perokok dan pengguna Napza, menciptakan hubungan antar warga sekolah yang lebih baik, akrab dan berkualitas, memudahkan pemantauan kondisi anak selama anak berada di sekolah, memudahkan mencapai tujuan pendidikan, menciptakan lingkungan yang hijau dan tertata, ciri khusus anak 
menjadi lebih betah di sekolah, anak terbiasa dengan pembiasaan pembiasaan positif.

Pemerintah Kota Depok telah melaksanakan Kebijakan SRA dalam rangka mewujudkan pemenuhan hak anak dan perlindungan anak sejak tahun 2016. Untuk mengetahui tentang perkembangan pelaksanaan dari Kebijakan SRA di Kota Depok maka diperlukan penelitian lebih mendalam tentang implementasi Kebijakan Sekolah Ramah Anak. Penelitian ini menggunakan teori Michael Hill dan Peter Hupe (2002) dalam menganalisis implementasi Kebijakan Sekolah Ramah Anak di SMP Negeri 6 Depok yang meliputi proses, hasil (output), dampak (outcome) dan hubungan sebab akibat (causal connection).

Proses (process). Sebelum adanya Kebijakan Sekolah Ramah Anak pada dasarnya tidak ada sekolah yang mengajarkan kekerasan. SMP Negeri 6 Depok telah menjadi piloting atau percontohan Sekolah Ramah Anak sejak tahun 2016. Implementasi Kebijakan Sekolah Ramah Anak telah dilaksanakan dengan baik. SMP Negeri 6 Depok telah berkomitmen dan mengikuti sosialisasi yang diselenggarakan oleh Dinas Pemberdayaan Anak, Masyarakat dan
Keluarga (DPAMK) dan Dinas Pendidikan Kota Depok tentang Kebijakan Sekolah Ramah Anak.

Sekolah berusaha memberikan layanan yang mempertimbangkan kebutuhan anak, keamanan dan kenyamanan anak di Sekolah diantaranya memenuhi sarana prasarana sekolah sesuai dengan pedoman (petunjuk teknis) Sekolah Ramah Anak seperti ruang terbuka, tempat bermain, pemisahan gender untuk toilet, tangga yang aman dan sebagainya walaupun kondisinya masih jauh dari standard Sekolah Ramah Anak karena terbatasnya sumber anggaran belanja modal. Tata tertib sekolah telah dibuat agar dapat melindungi anak dari kekerasan selama anak berada di lingkungan sekolah. Ekstra kurikuler sekolah juga telah mendukung untuk mengembangkan bakat dan potensi anak seperti Pramuka, Palang Merah Remaja, Paskibra, Rohis, Pencak Silat dan lain sebagainya.

Salah satu prinsip Sekolah Ramah Anak adalah non diskriminasi yang artinya setiap anak memiliki hak yang sama dalam mendapatkan pendidikan tanpa memandang status sosial, gender, ras, agama, perbedaan fisik dan sebagainya. Dalam upaya memenuhi kebutuhan pendidikan Anak 
Berkebutuhan Khusus (ABK), SMP Negeri 6 Depok telah menjadi sekolah inklusi yang melayani dan memenuhi Anak Berkebutuhan Khusus (ABK). Semua Anak Berkebutuhan Khusus (ABK) belajar bersama (membaur) dengan anak-anak normal lainnya namun ada perbedaan dalam perlakuan dan penilaian bagi anak berkebutuhan khusus (inklusi). Guru dan murid telah memahami bagaimana cara memperlakukan atau menghadapi anak yang berkebutuhan khusus sehingga anak tersebut merasa nyaman dan aman belajar di sekolah tanpa ada bullying dan kekerasan lainnya.

Sebagai Pembina, Kepala Sekolah SMP Negeri 6 Depok telah membentuk Tim Pelaksana Kebijakan Sekolah Ramah Anak yang meliputi Guru Bimbingan Konseling (BK), Guru Agama dan guru lainnya namun tugas fungsi belum dibuat secara tertulis. Para guru, anak murid dan orangtua sudah diberikan pemahaman tentang Kebijakan Sekolah Ramah Anak dan anti kekerasan melalui sosialisasi anti kekerasan dalam proses belajar mengajar yang ramah anak. Belum ada kegiatan khusus untuk implementasi Kebijakan Sekolah Ramah Anak, semua kegiatan sosialisasi anti kekerasan atau parenting education bisanya disisipkan pada kegiatan sekolah lainnya yang libatkan guru, murid dan orangtua.

Apabila terjadi kasus kekerasan di sekolah, para murid telah memahami mekanisme pengaduan yang telah tersedia. Pengaduan ditangani oleh Bidang Humas yang dikoordinir oleh Guru Bimbingan Konseling (BK). Jumlah Guru Bimbingan Konseling (BK) pada SMP Negeri 6 Depok sebanyak 3 guru yang tidak sebanding dengan jumlah murid sebanyak 1.048 siswa. SMP Negeri 6 Depok telah menyediakan beberapa saluran komunikasi antara Peer Counselor untuk penanganan kasus kekerasan dari anak ke anak dan juga saluran komunikasi guru dan orang tua. Sekolah juga bekerja sama dengan Psikolog dan Kepolisian untuk menangani kasus yang sudah tidak bisa diselesaikan oleh pihak sekolah. Anak korban kekerasan akan diberikan terapi oleh untuk menghilangkan terauma akibat kekerasan yang terjadi sehingga korban bangkit dan mau bersekolah kembali. Bagi pelaku kekerasan dikenakan sanksi hukum yang ditangani oleh pihak Kepolisian dan diberikan pembekalan pendidikan sosial agar tidak melakukan tindakan kekerasan kembali. 
Hasil (output), selama menjalani Kebijakan Sekolah Ramah Anak ada perubahan yang dirasakan oleh seluruh warga sekolah, khususnya anak murid. Sarana prasarana SMP Negeri 6 Depok seiring berjalan terus menerus menuju ke arah standard Sekolah Ramah Anak disesuaikan dengan kebutuhan anak. Tersedianya ruang bermain terbuka bagi anak dan lingkungan sekolah yang bersih, sehat dan asri membuat murid menjadi senang dan nyaman berlama-lama di sekolah begitu juga anak yang memiliki kebutuhan khusus juga dapat menikmati proses belajar dengan aman dan nyaman tanpa diskriminasi. Murid sudah berpartisipasi aktif dalam memberikan masukan atau pendapat untuk kepentingan sekolah melalui Organisasi Siswa Intra Sekolah (OSIS) atau saluran komunikasi yang tersedia di SMP Negeri 6 Depok. Komunikasi antara guru, murid dan orang tua juga terjalin dengan baik sehingga siswa tidak malu ataupun takut untuk melaporkan tindak kekerasan yang terjadi pada diri mereka.

Dampak (outcome), kebijakan Sekolah Ramah Anak mendorong seluruh warga sekolah untuk peduli terhadap lingkungan sekolah dan anti kekerasan sehingga suasana di sekolah menjadi sehat, aman dan nyaman. Kondisi yang kondusif mendorong anak didik dapat berkembang dan berprestasi di sekolah, salah satunya pada awal tahun 2019, SMP Negeri 6 Depok Depok berhasil meraih 5 mendali ( 2 emas, 1 perak dan 2 perunggu) pada Olimpiade Olahraga Siswa Nasional yang digelar di Gelanggang Olah Raga (GOR) Depok II Tengah untuk lomba Pencak Silat katagori siswa Sekolah Dasar (SD) dan Sekolah Menegah Pertama (SMP) seKota Depok.

Bukan hanya anak didik saja yang berprestasi namun para guru juga terdorong untuk menjadi lebih bersemangat dalam mengajar. Proses belajar mengajar menjadi lebih menyenangkan, kreatif dan interaktif yang mendorong gairah belajar pada anak sehingga anak mudah menyerap ilmu yang disampaikan oleh guru. Upaya pembentukan karakter anak menjadi salah satu hal penting untuk menciptakan anak menjadi manusia yang bertanggung jawab dan berakhlak mulia yang lebih penting dari kecerdasaan. Bentuk pembentukan karakter misalnya mendidik anak untuk jujur, bertanggung jawab, displin.

Hubungan sebab akibat (causal connection), pendidikan merupakan alat membangun masa depan bangsa dan 
negara yang harus menjadi perhatian utama pemerintah. Kebijakan Sekolah Ramah Anak adalah salah satu upaya dari pemerintah untuk memberikan layanan pada tunas bangsa agar dapat mengenyam pendidikan dengan menyenangkan, aman dan nyaman. Keberhasilan jangka pendek dari upaya pemerintah melalui implementasi Kebijakan Sekolah Ramah Anak dapat ditunjukkan dengan berbagai prestasi yang diraih oleh insan-insan pendidikan, baik guru maupun siswa. Keberhasilan jangka panjangnya adalah pendidikan yang dapat meningkatkan taraf hidup dan kesejahteraan masyarakat. Keberhasilan atau kegagalan pelaksanaan kebijakan disebabkan dari dukungan dari semua pihak termasuk pemerintah pusat. Sekolah sebagai pelaksanaan Kebijakan Sekolah Ramah Anak memerlukan dukungan, pendampingan dan stimulan dari pemerintah pusat dan pemerintah daerah sebagai pembuat kebijakan.

Faktor yang mempengaruhi Implementasi Kebijakan Sekolah Ramah Anak di SMPN 6 Depok

Dalam menganalisis faktor-faktor yang mempengaruhi implementasi Kebijakan Sekolah Ramah Anak di SMP Negeri 6 Depok menggunakan teori perpaduan dari Edward III, G dalam
Nugroho (2014) Shabbir Cheema dan Rondinelli dalam Subarsono (2005) yang menggali beberapa faktor yang terdiri dari komunikasi, disposisi, sumber daya, struktur birokrasi, hubungan antar instansi dan lingkungan.

Komunikasi, Penyampaian tujuan dan sasaran Kebijakan Sekolah Ramah Anak di SMP Negeri 6 Depok telah disampaikan dengan cukup baik melalui sosialisasi tentang anti kekerasan terhadap anak pada seluruh warga sekolah dan pelatihan kepada guru seperti tentang mengajar displin tanpa kekerasan. Komunikasi antara Kepala Sekolah, Guru, Murid dan Orang tua telah terlaksana dengan baik melalui parenting education yang disisipkan pada saat pertemuan sekolah dengan orang tua. Bimbingan dan arahan kepada murid yang disampaikan oleh Kepala Sekolah pada saat upacara sekolah dan guru pada saat pelajaran Bimbingan Konseling (BK). SMP Negeri 6 Depok juga menyediakan saluran-saluran komunikasi antara anak dengan anak, anak dengan guru dan guru dengan guru dan juga anak, guru dan orang tua.

Disposisi, Kebijakan Sekolah Ramah Anak disambut positif oleh seluruh warga SMP Negeri 6 Depok. Adanya Komitmen dari pihak Sekolah 
untuk menjalankan kebijakan ini dapat terlihat dari dibentuknya Tim Pelaksana Kebijakan Sekolah Ramah Anak oleh Kepala Sekolah SMP Negeri 6 Depok yang melibatkan Guru Bimbingan Konseling (BK), Guru Agama dan Komite Sekolah. Peningkatan pengetahuan dan kemampuan para pelaksana kebijakan yaitu guru, murid yang ditunjukan dengan proses belajar yang lebih menyenangkan, aman dan nyaman dan displin namun tanpa kekerasan. Adanya pengembangan proses belajar mengajar yang mampu membentuk karakter positif anak. Sikap guru yang dukungan implementasi Kebijakan Sekolah Ramah Anak di SMP Negeri 6 Depok dapat ditunjukan dari para guru berusaha bertanggungjawab untuk menjalankan implementasi Kebijakan Sekolah Ramah Anak selain itu komitmen juga ditunjukan dengan peningkatan layanan mengajar dengan lebih baik dan ramah kepada anak dan kualitas komunikasi yang lebih intensif dengan orang tua terkait dengan perkembangan pendidikan akademik anak.

Sumber Daya, sarana prasarana sekolah sudah cukup memadai namun masih perlu pengembangan yang lebih lanjut untuk kearahan Sekolah Ramah
Anak. Hal ini terlihat dari kondisi sekolah yang cukup memadai bagi siswa seperti tersedia lapangan sekolah sebagi tempat bermain anak di luar jam sekolah, toilet yang terpisah berdasarkan gender, kantin sekolah yang cukup higienis dan aman bagi kesehatan, perpustakaan, Usaha Kesehatan Sekolah (UKS), ruang konseling dan sebagainya namun kondisi masih belum memadai apabila merujuk pada kondisi Sekolah Ramah Anak yang ideal karena terkendala anggaran sekolah yang terbatas karena sumber anggaran menggunakan dana Bantuan Operasional Sekolah (BOS) dan adanya regulasi dari pemerintah terkait pengelolaan anggaran belanja modal yang membatasi ruang gerak sekolah untuk mengembangkan sarana dan prasarana sekolah menjadi ramah anak. Terbatasnya jumlah guru yang menjadi tim pelaksana kebijakan dan padatnya aktivitas guru di sekolah sehingga program/kegiatan yang mendukung pelaksanaan kebijakan ini belum menjadi skala prioritas.

Struktur Birokrasi, kepala Sekolah SMP Negeri 6 Depok telah membentuk tim pelaksana Kebijakan Sekolah Ramah Anak yang melibatkan para guru, komite sekolah, OSIS namun untuk tugas pokok dan fungsi dari masing-masing anggota tim pelaksana 
belum dibuat secara tertulis. Meskipun belum dibuat secara resmi, tim pelaksana telah berupaya menjalankan tugas dan fungsinya sesuai dengan pedoman Kebijakan Sekolah Ramah Anak.

Hubungan antar Organisasi, pemerintah Daerah Kota Depok melalui Dinas Pemberdayaan Anak, Masyarakat, dan Keluarga (DPAMK) telah melakukan sosialisasi Kebijakan Sekolah Ramah Anak dan pendampingan terhadap sekolah di kota Depok dengan berkoordinasi dengan Dinas Pendidikan Kota Depok sebagai instansi yang menetapkan Sekolah Ramah Anak. Dinas Pendidikan Kota Depok memberikan arahan dan pendampingan ke sekolah. Kepala Sekolah sebagai penanggungjawab pelaksanaan Kebijakan Sekolah Ramah Anak mendorong dan mengarahkan semua warga sekolah untuk mendukung pelaksanaan kebijakan. Hubungan antar organisasi belum bersinergi secara optimal sehingga kendala-kendala yang timbul pada saat pelaksanaan kebijakan tidak tersampaikan ke Pemerintah Pusat sebagai pembuat kebijakan sehingga masih banyak kebutuhan anak belum terpenuhi secara memadai.

Lingkungan, perkembangan sosial anak-anak berada di bawah pengaruh keluarga, teman sebaya dan sekolah, dan lingkungan. Warga sekolah selain kepala sekolah, guru dan murid juga ada orang tua, penjaga sekolah (satpam), cleaning service, penjual makanan di kantin sekolah biasanya berasal warga sekitar lingkungan SMP Negeri 6 Depok. Pihak sekolah secara intensif telah melakukan pendekatan secara informal untuk memberikan pengarahan dan pengawasan mereka sehingga mendukung menciptakan lingkungan sekolah yang sehat, aman dan nyaman bagi seluruh warga sekolah khususnya siswa.

Implementasi Kebijakan Sekolah Ramah Anak didukung oleh Komunikasi yang baik dan lancar, sikap dan komitmen para guru dan seluruh warga SMP Negeri 6 Depok Kebijakan Sekolah Ramah Anak di SMP Negeri 6 Depok, hal ini ditunjukkan antara lain dengan adanya tim pelaksana kebijakan yang bertanggung jawab pada pelaksanaan kebijakan secara konsisten dan berkelanjutan; peningkatan kualitas pelayanan Pendidikan yang ramah anak tanpa diskriminasi dan terjalin koordinasi yang cukup baik antara Pemerintah Daerah Depok dengan Sekolah serta adanya dukungan positif seluruh warga sekolah, orang tua maupun masyarakat sekitar. 
Seiring berjalannya Kebijakan Sekolah Ramah Anak ini banyak hambatan yang dihadapi antara lain terbatasnya anggaran sekolah untuk mendukung pengembangan sarana dan prasaran sekolah ke arah kondisi Sekolah Ramah Anak yang ideal dan terbatasnya jumlah guru serta padatnya aktivitas guru sehingga pelaksanaan kebijakan belum optimal dalam memenuhi standard Sekolah Ramah Anak.

\section{SIMPULAN}

Berdasarkan hasil penelitian Implementasi Kebijakan Sekolah Ramah Anak di SMP Negeri 6 Depok telah berjalan dengan baik apabila dinilai dalam konteks proses, hasil (output), dampak (outcome) dan hubungan sebab akibat (causal connection). Pelaksanaan kegiatan telah memberikan hasil dan dampak potistif sesuai sasaran dan tujuan dari Implementasi Kebijakan Sekolah Ramah Anak. Meskipun sudah berjalan dengan baik masih perlu pengembangan baik dari segi sarana dan prasarana sekolah, sumber daya manusia, sumber finansial, dukungan dari seluruh warga sekolah, masyarakat, pemerintah pusat dan pemerintah daerah.

Faktor-faktor yang mendukung implementasi Kebijakan Sekolah Ramah
Anak di SMP Negeri 6 Depok adalah komunikasi yang baik dan lancar, sikap dan komitmen para guru dan seluruh warga, terjalin koordinasi yang cukup baik antara Pemda Depok dengan Sekolah serta adanya dukungan positif seluruh warga sekolah, orang tua maupun masyarakat sekitar. Namun sisi lain masih terdapat hambatan yang dihadapi yaitu terbatasnya anggaran untuk mendukung pengembangan sarana dan prasarana dan terbatasnya jumlah guru serta padatnya aktivitas guru sehingga pelaksanaan kebijakan belum optimal dalam memenuhi kebutuhan anak yang sesuai standard Sekolah Ramah Anak.

\section{DAFTAR PUSTAKA}

Abidin, Said, Zainal. 2002. Kebijakan Publik Edisi Revisi. Yayasan Pancur Siwah.

Artadianti, Kiki. 2015. Implementasi Sekolah Ramah Anak (SRA) pada Sekolah Percontohan di SD Pekunden 01 Kota Semarang Sebagai Upaya Untuk Mendukung Program Kota Layak Anak (KLA). Journal Public Policy and Management Review, Volume 6, Nomor 3, Tahun 2017.

Djamaludin, Nanang, 2018, Cermin Ringkihnya KLA dan SRA di Kota Depok, diunggah pada tanggal 3 Maret 2019 dari https://www.watyutink.com/opini/Ce rmin-Ringkihnya-KLA-dan-SRA-diKota-Depok. 
Dunn, William. 2004. Public Policy Analysis: An Introduction, New Jersey: Pearson Education. Edisi Bahasa Indonesia diterjemahkan pada edisi ke 2 (1994) diterbitkan sejak 1999 dengan judul Pengantar Analisis Kebijakan Publik, Yogyakarta: Gajah Mada University pres.

Dye, Thomas R. 2011. Understanding public policy. New Jersey: Pranticehall

Grindle, M. 1980. Politic and Policy Implementation in The Third, New Jersey: Princeton University Press.

Hill, Michael dan Hupe, Peter. 2002. Implementing Public Policy. Sage Publication Ltd. London.

Kementerian Pendidikan dan Kebudayaan (Kemendikbud). 2017. Ikhtisar Data Pendidikan Tahun 2016/2017. Jakarta. Kementerian Pendidikan dan Kebudayaan (Kemendikbud).

Nugroho, Riant. 2014. Public Policy (Teori, Manajemen, Dinamika, Analisis, Konvergensi dan Kimia Kebijakan). Edisi Kelima Revisi, PT. Elex Media Komputindo.

Peraturan Daerah Kota Depok Nomor 15 Tahun 2013 tentang Penyelenggaraan Kota Layak Anak

Peraturan Walikota Depok Nomor 10 Tahun 2017 tentang Pengembangan Kota Layak Anak

Saraswati, Rika. 2015. Hukum Perlindungan Anak di Indonesia. Semarang. PT Citra Aditya Bakti

Sari, Ayu Kartika. 2017. Implementasi Program Sekolah Ramah Anak Dalam Penangulangan Kekerasan Pada Anak di SDN 3 Panggung Rejo Kabupaten Pringsewu, Unversitas Lampung.
Sekolah Anak.Com. 2018. Sekolah Ramah Anak di unduh pada tanggal 10 Maret 2019 dari https://sekolahanak.com/sekolahramah-anak.html

Subarsono, AG. 2005. Analisis Kebijakan Publik (Konsep, Teori dan Aplikasi). Cetakan VII September 2015, Pustaka Pelajar. Yogyakarta.

Undang-Undang Nomor 23 Tahun 2002 tentang Perlindungan Anak

Undang-undang Nomor 35 Tahun 2014 tentang Perubahan atas UU Nomor 23 Tahun 2002 tentang Perlindungan Anak.

UNICEF. 2012. Child Friendly School. diunggah tanggal 5 Mei 2019 dari https://www.unicef.org/lifeskills/inde x_7260.html.

Utari, Ranti Eka. 2017. Implementasi Program Sekolah Ramah Anak di SMP Negeri 1 Tempura Kabupaten Magelang, Universitas Negeri Yogyakarta.

VOAIndonesia.com, KPAI : Kasus Kekerasan Anak dalam Pendidikan Meningkat Tahun 2018, diperoleh tanggal 3 Februari 2019 dari https://www.voaindonesia.com/a/kpa i-kasus-kekerasan-anak-dalampendidikan-meningkat-tahun2018/4718166.html

Winarno, Budi. 2016. Kebijakan Publik Era Globalisasi (Teori, Proses dan Studi Kasus Komparatif), CAPS, Yogyakarta

Yuliani, Wahyu Intan. 2015. Implementasi Perwali Kota Surakarta Nomor 28D Tahun 2014 Tentang Sekolah Ramah Anak (Studi di SD Muhammadiyah 16 Karangasem dan SD Muhammadiyah Program Khusus (PK) Kota Barat). Universitas Sebelas Maret Surakarta. 